
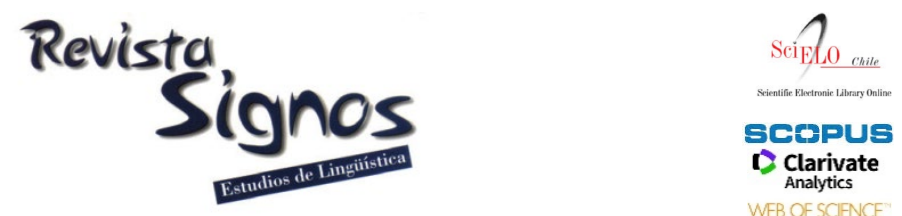

\title{
Authorial visibility in the introduction and post- methodology sections of research papers from different disciplines*
}

\author{
La presencia del autor en la sección de introducción y post- \\ metodología en articulos de diferentes disciplinas
}

\author{
$\mathrm{M}^{\mathrm{a}}$ Milagros del Saz Rubio \\ Departamento de Lingüística APLiCADA \\ UNIVERSITAT POLITĖCNICA DE VALĖNCIA \\ ESPAÑA \\ masaru@idm.upv.es
}

Received: 23-IX-2019 / Accepted: 30-XI-2020

DOI: $10.4067 /$ S0718-09342021000200600

\begin{abstract}
Recent studies have shown that academic writing is not completely impersonal. Rather, the writers' presence is part and parcel of academic prose as authors need to portray a convincing authorial voice, while also being able to tentatively present their claims and findings (Hyland 2001a; 2002b). One of the rhetorical strategies at the researchers' disposal is the use of personal pronouns and their corresponding determiners (Tang \& John, 1999; Martínez, 2005; Mur-Dueñas, 2007). With this in mind, a corpus of 30 research papers from the disciplines of engineering, medicine and linguistics will be examined in order to first assess the traces of authorial presence through the use of personal pronouns, and their corresponding determiners, or noun phrases such as 'the authors', 'the researchers', together with their function across the introduction and the sections which report findings and/or discuss them. Findings show significant differences from a statistical point of view in both the way and frequency with which authors from each discipline make themselves visible in the different sections under analysis. While all disciplines show a preference for the use of explicit authorial devices, engineering relies more on other indirect or implicit ways of author presentation. Medicine, on its part, is the discipline which employs more authorial devices per 1,000 words in spite of the fact that its articles are shorter, and its sections are much less rhetorically complex if compared to those of Linguistics and Engineering.
\end{abstract}

Key Words: Authorial presence, explicit, implicit and indirect authorial devices, research papers, soft and hard disciplines. 


\section{Resumen}

Estudios recientes han puesto de manifiesto que la escritura académica no es impersonal, sino que la presencia del escritor es clave en la prosa académica, ya que los investigadores no solamente necesitan mostrar una voz convincente sino además deben ser capaces de presentar sus resultados de forma tentativa (Hyland 2001a; 2002b). Uno de los mecanismos retóricos a disposición de los investigadores es el uso de los pronombres y sus determinantes (Tang \& John, 1999; Martínez, 2005; Mur-Dueñas, 2007). En este estudio se analizan 30 artículos de investigación de tres disciplinas: ingeniería, medicina y lingüística. En primer lugar, se examinarán las auto-menciones como huellas de la presencia del autor a través de estos pronombres y sus demostrativos, junto con expresiones como 'los autores', 'los investigadores'. Además, se analizarán las funciones desempeñadas en las secciones de introducción y en las posteriores a la metodología. Los resultados han indicado que hay diferencias estadísticamente significativas tanto en la forma como en la frecuencia de uso de las auto-menciones que indican la presencia del autor en las tres disciplinas y en las diferentes secciones analizadas. Aunque todas las disciplinas muestran una preferencia clara hacia el uso de elementos explícitos, es la ingeniería la disciplina que más recurre a elementos indirectos o implícitos para llevar a cabo la automención. La medicina es la disciplina donde más presencia del autor existe por 1.000 palabras, aunque sus artículos son los más cortos, y es la disciplina menos compleja desde un punto de vista retórico comparada con la Lingüística y la Ingeniería.

Palabras Clave: Elementos de auto-mención, mecanismos explícitos, implícitos e indirectos, artículos de investigación, disciplinas duras y blandas.

\section{INTRODUCTION}

Academic writing has been traditionally viewed as objective, impersonal and even author-evacuated writing (Geertz, 1983; Hardwood, 2005a, 2005b). As a result, the dominant view has considered that writers had to eradicate themselves from their texts and avoid intruding into their own discourse. This was the norm in style guides or books, which traditionally recommended writers to avoid any trace of personal reference when dealing with the writing of science in order to make it more objective and, hence, to make the researcher more credible (Rowntree, 1991; Lester, 1993, among others). The choice of an impersonal and objective style has also been linked with both the writing traditions and the epistemological beliefs of the disciplinary community to which writers belong (McDonald, 1992; Hyland 2000; Shaw, 2003; Hyland \& Tse, 2005; Shaw \& Vassileva, 2009).

In spite of this generalized view, a great deal of research dating back from the mid and late $90 \mathrm{~s}$ and onwards has shown otherwise. It seems that writers do, indeed, aim to create a successful interpersonal interaction with their readers when reporting their scientific findings. This interpersonal relationship has been shown to be achieved through the use of various linguistic devices such as metadiscoursal features (Hyland, 2005; Carrió-Pastor 2019; Abdollahzadeh, 2010; Bondi, 2010), boosters (Carrió-Pastor \& Muñiz-Calderón, 2015), hedges (Bloor \& Bloor, 1991; Hyland 1994, 1996, 1998, 
Carrió-Pastor, 2016), evaluative language or stance (Thompson \& Ye, 1991; Hunston, 1993, 1994), reporting verbs (Thompson \& Ye, 1991; Hyland, 1999), or the use of first person pronouns or authorial references (cf. Ivanič, 1994, 1995, 1998; Luzón, 2006; Vassileva, 1998, 2000, 2001; Kuo, 1999; Tang \& John, 1999; Hyland 2001a, 2001b, 2002a, b; Ivanič \& Camps, 2001; Breivega, Dahl \& Flottum, 2002; Harwood 2005a, 2005b; Flottum, Kinn \& Dahl, 2006, among many others).

In particular, what the body of research on first person pronouns or authorial devices has come to indicate is that they constitute key rhetorical and marketing strategies that researchers can use to persuade their peers about the validity of their claims, while creating a competent and reliable image of themselves as rational and credible members of the discipline. Not in vain, researchers are more than ever faced with the need to position their work in the competitive publishing market, and to highlight the originality of their contributions while underscoring their uniqueness (Berkenkotter \& Huckin, 1995; Hardwood, 2005). In fact, as Lorés-Sanz (2011b: 31) states: "one of the features that characterize the presentation of scientific discourse in academic texts is the way authors construct the voice that they project onto the text".

In other words, academic writing, far from merely conveying facts in an impersonal way, opens up room for the negotiation of interpersonal aspects. Thus, authorial visibility is carefully constructed and encoded in academic writing as a way of signalling how researchers relate to their arguments, their peers, the culture and the scientific community to which they belong (Lorés-Sanz, 2011a, 2011b). Despite the fact that personal pronouns have received prolific attention in the literature, the topic remains a controversial one (Hyland, 2001a; Martínez, 2005) as not only students, but also novice and consolidated researchers, remain unsure about when and how to intrude into their own writing (Connor, 1996; Cadman, 1997; Chang \& Swales, 1999; Hyland, 2001a), especially those writing in English as an L2.

What is more, recent research has shown that the use of personal pronouns can be subject to differences across genres (Fortanet, 2004; Albalat-Mascarell \& CarrióPastor, 2019), disciplines (Hyland, 2001a, 2001b; Harwood 2005a, 2005b), and to differences dictated by the epistemological aspects of the discipline or community to which the writers belong (Hyland 2002a, 2002b; Lafuente-Millán, 2010; Lorés-Sanz, 2011a). Since culture is also a key aspect in determining how writers portray an image of themselves, there have been studies within the field of contrastive rhetoric which have explored the use of authorial voice in RAs written by English L1 researchers and by Spanish scholars writing in Spanish (L1) and in English (L2) (cf. the work of LorésSanz, 2004; 2011a, 2001b; Martínez, 2005; Mur-Dueñas, 2007, Carciu, 2009).

Against this backdrop, the aim of this paper is, thus, to somehow contribute to the current debate on the use of authorial references by looking into how authorial devices are employed by English L1 researchers in three unrelated disciplines across 
the two most rhetorically charged sections of research papers (Gosden, 1993), that is, the introduction and post-methodology sections ${ }^{1}$.

The decision to analyse how the writers' voice is conveyed in RAs written by English L1 researchers should be understood as a preliminary stage in an attempt to obtain reliable results for further contrastive analyses. In other words, the decision to focus on the rhetorical choices made by native speakers can be justified on several additional grounds: first, it is well-known that it is imperative for scholars to publish their research in English in order to obtain a higher impact, scope, or visibility (Flowerdew \& Li, 2009; Li, 2014; McGrath, 2014). However, extensive research has echoed the pressures and problems that non-Anglophone writers face when having to publish their research in English in high-rank journals (Salager-Meyer, 2014; Li, 2014; Martín-Martín, Rey-Rocha, Burgess \& Moreno, 2014; Moreno, Rey-Rocha, Burgess, López-Navarro \& Sachdev, 2012). Such problems are sometimes related to their linguistic competence and proficiency in English, but are also motivated by a lack of awareness of the disciplinary conventions of the specific discipline and community in which the research takes place. As a result, as stated in Moreno and Swales (2018), Spanish researchers have expressed their willingness to undergo some kind of training in writing for publication in English (Burgess, Gea-Valor, MaL1, Moreno \& ReyRocha, 2014). In particular, research has pointed to a need for training in specific areas of academic writing such as the writing of the rhetorical sections of the RA or the use of metadiscoursal units (López, Moreno \& Rey-Rocha, 2017; Moreno et al., 2012). Taking all these reasons into consideration, I firmly believe that even if a high percentage of the researchers publishing in top journals is nowadays of non-anglophile origin, they nonetheless strive to 'sound' and 'write' like native speakers in order to conform with the journals' expectations, which are, in turn, a reflection of the epistemological community to which they belong.

To make the objective of this paper more manageable, this piece of research will address and answer the following research questions:

i. What are the devices most frequently employed by researches to signal their presence in the text in the introduction and post-methodology sections of the RAs?

ii. What are the pragmatic functions deployed by these devices across these RAs sections?

iii. What are the similarities and/or differences in the frequencies of use of explicit first person pronouns, and the indirect/implicit devices across sections and disciplines? 


\subsection{Previous taxonomies}

Several studies have focused on the functional-pragmatic effects that personal pronouns help create in academic writing (Vassileva, 1998; Kuo, 1999; Tang \& John, 1999; Hyland, 2001a, 2001b, 2002a, 2002b; Hardwood, 2005a, 2005b). Thus, authorial devices have been found to be of use for researchers to organize their discourse, state opinions and claims, recount methods and procedures and acknowledge individuals or institutions which participated in the research, as their most outstanding functions. In this section, I will briefly review the main taxonomies which have been taken as a starting departure point for the elaboration of my own taxonomy.

First of all, Tang and John's study (1999) explore the notion of writer identity in academic essays by looking at person pronouns. They set up a typology of six identities drawing on Ivanic's previous work $(1994,1995,1998)$ in order to examine essays written by first-year undergraduates. Tang and John's (1999) taxonomy identifies the different roles that students can bring into their writing through the use of person pronouns. They also place such roles along a continuum in terms of the degree of authorial power enacted; that is, some of the roles point to a more or less powerful authorial presence:

a) the representative: "a generic first-person pronoun, usually realized as the plural 'we' or 'us', that writers use as a proxy for a larger group of people" (Tang \& John, 1999: 27).

b) the 'guide' or the person who "shows the reader through the essay (...) draws the reader's attention to points which are plainly visible or obvious within the essay" (Tang \& John, 1999: 27).

c) the 'architect': "the person who writes, organizes, structures, and outlines the material in the essay" (Tang \& John, 1999: 27).

d) the recounter of the research process: the researcher "who describes or recounts the various steps of the research process" (Tang \& John 1999: 28).

e) the opinion holder: "a person who shares an opinion, view or attitude (for example, by expressing agreement, disagreement or interest) with regard to known information or established facts" (Tang \& John, 1999: 28) ${ }^{2}$.

f) the originator: as the person who indicates "the writer's conception of the ideas or knowledge claims which are advanced in the essay", which "calls for the writer to present or signal these as new" (Tang \& John, 1999: 29).

On its part, Hyland (2002b), in his study of project reports written by Hong Kong undergraduates, identifies five main discourse functions for the exclusive pronoun 'we' in RAs. Unlike previous taxonomies, Hyland excludes inclusive uses of 'we' from the category of the metadiscoursal elements he terms 'self-mentions': (a) expressing self-benefits; (b), stating a purpose; (c) explaining a procedure; (d) elaborating an argument and (e) stating results/claims. The first function is meant to be understood 
within the context of the research carried out and it is normally excluded as irrelevant with a different corpus of analysis.

Hardwood (2005a), in his qualitative corpus-based study, aims to look into the promotional roles of I and we across several disciplines, some of which were not previously included in Hyland's (2001a) study, i.e., Business and Management, Economics and Computing. He states that the pronouns $I$ and we help authors promote their work both in the soft and hard disciplines, especially at the start and close of the RA by helping fill in a gap, presenting claims and repeating them in the closing sections, while also disputing other's claims and stressing their own methodological contributions or by self-citing themselves.

While most researchers on authorial references base their studies on either Tang and John's or Hyland's typologies (Lorés-Sanz, 2011a), others slightly modify and/or adapt them to fit their own needs, depending on their corpus of analysis. This is the case of Lafuente-Millán (2010) who carries out a study on disciplinary variation in order to suggest a refined categorization of the main discourse functions of selfmention strategies. His taxonomy, driven by the analysis of his corpus, includes the following functions:

a) Structuring the information or moves present in the article/referring backwards or forward.

b) Stating a goal or purpose.

c) Explaining the procedures, steps or research decisions taken.

d) Stating expectations, hypotheses, beliefs or agreement with a particular view.

e) Stating results or findings and

f) Making claims or assertions.

My taxonomy draws on previous studies, especially Hyland's framework, and has been driven by direct observation of the data under examination. The labels selected for each function are the ones which, in my opinion, best describe the communicative functions performed at each rhetorical stage in the introduction and post-method sections and are as follows:

a) Stating goals

"Given this dilemma, the aim of this study was to determine the extent to which strength and familiarity of accent affect comprehension and provide a defensible direction for assessing multidialectal listening comprehension for listening assessments" [Applied Linguistics 2016, 35 p. 2] 
b) Explaining procedures

"For that reason, we performed ROC analysis to assess the predictive capabilities of both approaches in regard to occurrence of PAR. [JACC Cardiovascular Interventions. 2017, 24, 10(8), p. 819]

"Because of aortic annular dimensions being larger in systole than in diastole (13) and to increase the reliability and applicability of our analysis, we purposefully only included patients with available CT systolic annular dimensions." [JCC Cardiovascular Interventions. 2017,24;10(8), p. 8171

c) Stating results or claims

"Here, we found two key contrasts - differences between cities and between fill and pre-existing soil classes" [Plant Soil, 2017, 41(3), p.55].

d) Elaborating an argument

"This study found template use to be problematic insofar as the customers appeared to treat the agent questions and responses as 'robotic"'. [English for Specific Purposes 2017, 47, p. 38]

Specifically, our findings seem to indicate an effect of marketization on the higher education sector (Fairclough, 1992), and more broadly, the impact of the forces of "New Orders" (Gee, Hull, \& Lankshear, 1996; Robinson-Pant \& Street, 2012) that have increasingly pervaded academia in the past decades. [Journal of English for Academic Purposes, 17, 26, p.63-64]

We might suggest that the latter category of feedback though placed under prompting engagement with academia in our categorization indicates that the lecturers in our sample, like the supervisors in Anderson et al. (2006) expecting a Master's dissertation in education to be "informed by theory" (p. 154), seemed to encourage a theory-practice nexus. Journal of English for Academic Purposes, 17, 26, p.61].

e) Expressing a limitation

"The present study was restricted to the subsample of 3119 veterans. Veteran status was assessed using the question: "Have you ever served on Active Duty in the U.S. Armed Forces, Military Reserves, or National Guard" [Journal of Psychiatrist Res 2016, 82, p. 3]

"Statistical measures to quantify the model performance (Table 3) help to judge the error of predictions made with the model. However, we acknowledge that a proper uncertainty analysis would have been even more beneficial. [European J. of Agronomy 2017, 82, p.264]" 
f) Indicating a contribution or application

"To our knowledge, the current study is the first in the oncology informed consent literature that sought to apply readability measures designed for the written word to the transcribed spoken word". [Cancer 2016, 122(3), p.467]

g) Pointing to future work:

"Further increased connectivity between amygdala and the temporal pole may also be an indicator of resilience to clinical depression in the future, we believe this is certainly worth investigating further. [J Psychiatr Res. 2016, 82, p.12]

h) Organizing discourse

"This paper is organized as follows. Section II presents a review of related works. Section III introduces a formalism for IEC 61499 and a description..." [IEEE Transactions on Industrial Informatics 12(1), p. 59]

On the one hand, my taxonomy includes pragmatic functions a)-e) which have already been considered in Hyland's taxonomy and partly in that by Lafuente-Millán (2010) and Tang and John (1999). However, my proposal incorporates additional pragmatic functions to those already identified in other frameworks of analysis. In particular, authorial devices have been found to be employed to fulfil the functions of expressing limitations, or indicating the contribution or application of the research, while also pointing to the work that remains to be done. I have also made a distinction between the functions of 'stating results or a claim' and 'elaborating an argument'. By elaborating an argument, I understand examples where the researchers go beyond the presentation of a finding and elaborate on it through the use of metadiscoursal devices such as hedges, boosters or other devices in an attempt to provide their own interpretation of the finding. In other words, attention to the cotext, that is, 'the immediate linguistic environment in which a unit of discourse...occurs...in a discourse sequence' is key for discerning between these two functions (Hardwood, 2005a for similar insights). In other words, elaborating on an argument brings with it a higher involvement on the part of the speaker, and a higher face threat than merely reporting a finding, or announcing a goal.

\section{Research methods}

\subsection{Corpus collection procedure}

The corpus of analysis is made up of 30 multi-authored RAs collected from highimpact internationally refereed journals on the basis of the three criteria stated by Nwogu (1997), i.e., representativity, reputation and accessibility. Two articles were 
selected from five different publications in each of the disciplines (See Appendix I). The corpus of analysis, which did not comply with the IMRD structure (Introduction, Method, Results and Discussion), comprised the introduction and post-methodology sections of RAs in the three disciplines: Engineering, Linguistics and Medicine.

In fact, as Lin and Evans' (2012: 153) already noted, "IMRD is far from being the default option for organizing contemporary empirical RAs". Thus, for the purpose of this paper, I will first focus on the introductions of all the 30 RAs for traces of authorial devices. Law and Williams (1982: 539) have shown that introductions are key promotional sections, insofar as they are "designed to alert potential users, to persuade them that this is a valuable product, one which they cannot do without". In this respect, it would be interesting to assess the degree to which researchers selfpromote themselves in a more or less explicit fashion considering this section is a "prime site for self-promotion" (Hardwood 2005a: 1216).

The other sections of the RA under analysis are the post-method sections, that is, results, discussion and conclusion sections, which have been conflated or merged into one (see Del Saz-Rubio, 2019). It is in these sections where researchers present new findings, justify and explain them, while contextualizing results within the wider scientific community and thus, their credibility and persona is at stake (Cherry, 1988). The rhetorical functions proper of these sections entail a higher degree of personal involvement and it is, thus, my aim to assess the degree of authorial presence, from a range of more to less explicit authorial devices, which is enacted across different disciplines in order to account for disciplinary variations ${ }^{3}$.

The articles selected are part of the corpus compiled for the research project "Identification and analysis of rhetoric elements in Spanish and in English: study of metadiscoursive strategies", financed by the Spanish Ministry of Economy, Industry and Competitiveness (FFI2016-77941-P). In its first stage, this project was concerned with the annotation and identification of metadiscoursal devices in the three main disciplines under analysis. All the texts were electronically extracted from scientific journals included in the Social Science Citation Index and Science Citation Index Expanded (Web of Science) from the years 2016-2018. Since the sources of these texts were selected bearing in mind the need to ensure the highest quality of research reported and of English language use, just those texts written by native-proficiency speakers of English were chosen. Native proficiency was determined by the personal details included (name, surname, affiliation). The three sub-corpora yielded a total of 117,208 words.

\subsection{Data analysis procedure}

In order to avoid the subjectivity that the analysis of one sole researcher may bring to the study, a Linguistics $\mathrm{PhD}$ student was asked to code the introduction and post- 
method sections of 16 RAs and intercoder reliability exceeded 80\% (0.8655), hence indicating an outstanding level of interrater agreement (Landis \& Koch, 1977).

In a later stage, and in order to identify the different self-mention devices employed, I carried out an electronic computer search with WordSmith 5.0 and a personal manual reading of the different sections to identify other possible authorial devices and to verify that the elements were used in this role. In order to account for any statistical difference between the frequencies of use that writers from the different disciplines make of authorial references, their raw frequencies were normalized per 1,000 words and chi square was calculated with a significance value of $\mathrm{p} \leq 0.05$. Table 1 below shows the list of devices searched for electronically:

Table 1. List of authorial devices.

\begin{tabular}{|l|}
\hline EXPLICIT SELF-MENTION DEVICES \\
\hline I \\
\hline me \\
\hline my \\
\hline myself \\
\hline mine \\
\hline We \\
\hline us \\
\hline our \\
\hline ours \\
\hline ourselves \\
\hline INDIRECT SELF-MENTION DEVICES \\
\hline Author(s) \\
\hline Researcher(s) \\
\hline IMPLICIT SELF-MENTION DEVICES \\
\hline study \\
\hline research \\
\hline paper \\
\hline article \\
\hline investigation \\
\hline work \\
\hline objective \\
\hline aim \\
\hline
\end{tabular}

For the purpose of this article, I have labelled the use of first person pronouns and their corresponding possessive pronouns 'explicit', as the most visible devices, whereas the use of words such as 'the author(s)' or 'the researcher(s)' has been term indirect devices. Implicit self-mention devices roughly correspond to the so-called 'abstract rhetors' (Thompson \& Thetela 1995) which can be considered a "depersonalizing strategy" (Sancho-Guinda, 2015) or nouns which "designate inanimate or collective referents and relieve the authors of agency" (Sancho-Guinda, 2015: 139). Hyland (1998) suggest that these devices occur with judgmental and speculative lexical verbs and indicate that the action can be achieved without human intervention ${ }^{4}$. 
The identification of the different functions performed by the authorial devices under analysis was somehow determined or guided by the rhetorical function of the specific section where they were used. The findings obtained here are only extendable to similar RAs in the field.

\section{Findings}

The findings of this study will be structured in two main sub-sections that will provide an answer to the research questions that motivated the analysis. First, the quantitative results of authorial devices will be presented in order to account for the similarities and/or differences in their frequencies of use and distribution across the two main RAs sections under analysis. Finally, the main discourse/pragmatic functions will be qualitatively and quantitatively described.

\subsection{Frequency of use and distribution of authorial devices across the three disciplines and sections}

In order to account for any statistical differences between the frequencies of use that researchers from the three disciplines make of authorial devices, I first quantified the raw counts for the different types of authorial references (i.e., explicit, indirect and implicit self-mention) both in the introduction and post-methodology sections of the selected engineering, linguistics and medicine RAs. In a later stage, and to make the three corpora comparable, I normalized these raw frequencies per 1,000 words. The statistical tool chi square was calculated with a significance value of $\mathrm{p} \leq 0.05$. Table 2 below shows the number of running words for each of the corpora under analysis, the raw counts, their percentages and their frequencies normalized to 1,000 words.

Table 2. Running words, raw features, normalized frequencies and overall percentages of authorial devices per 1,000 words across disciplines.

\begin{tabular}{|l|c|c|c|c|}
\hline DISCIPLINE & Running words & Raw features & $\begin{array}{c}\text { Normalized Frequency } \\
(\mathbf{1 , 0 0 0} \text { wds })\end{array}$ & $\mathbf{\%}$ \\
\hline Engineering & 37,895 & 137 & 3.6 & 23.9 \\
\hline Linguistics & 55,823 & 289 & 5.2 & 50.4 \\
\hline Medicine & 23,490 & 147 & 6.3 & 25.7 \\
\hline Total & 117,208 & 573 & $\mathbf{4 . 9}$ & 100 \\
\hline
\end{tabular}

Findings indicate that the number of running words is considerably higher in Linguistics papers, as is also the amount of raw counts identified, i.e., 289, which represents $50.4 \%$ of all the authorial devices deployed. However, the normalized frequencies describe a somewhat different picture. In fact, researchers writing papers in the field of Medicine are the ones who employ authorial references with a higher frequency (6.3 per 1,000 words), compared to the rest, with 3.6 per 1,000 words in the field of Engineering and 5.2 in the field of Linguistics. On average, authorial 
references are employed with a frequency of 4.9 per 1,000 words in the three corpora analysed.

These results somehow indicate that researchers deploy their own rhetorical stance when establishing and maintaining an authorial persona in the different disciplines, and they seem to help corroborate the traditional distinction between the soft and hard disciplines regarding the use of authorial devices. Hyland (2001a), for example, found that first person pronouns and self-citation were less pervasively employed in Mechanical Engineering compared to disciplines in the social sciences and the humanities. In fact, $3 / 4 \mathrm{~s}$ of all the first person pronouns found in Hyland's study occurred in the humanities and social sciences and they were hardly used in Mechanical Engineering.

With regard to the frequency of occurrence of the different types of authorial devices, it should be noted that explicit authorial devices have been found to be employed with a higher frequency in the disciplines of Medicine and Linguistics (across both sections) (see Figure 1 below). On the contrary, Engineering RAs display a much more balanced use of explicit (1.6) and implicit/indirect self-mention devices (1.5) per 1,000 words. This finding is in line with Hyland's research of authorial presence in eight different disciplines. In his study he found that 'we and $I$ were the most commonly used devices for self-representation in the texts' (Hyland, 2001'), compared to other forms such as self-citation and, to a lesser degree, other ways of referring to the authors of the paper.

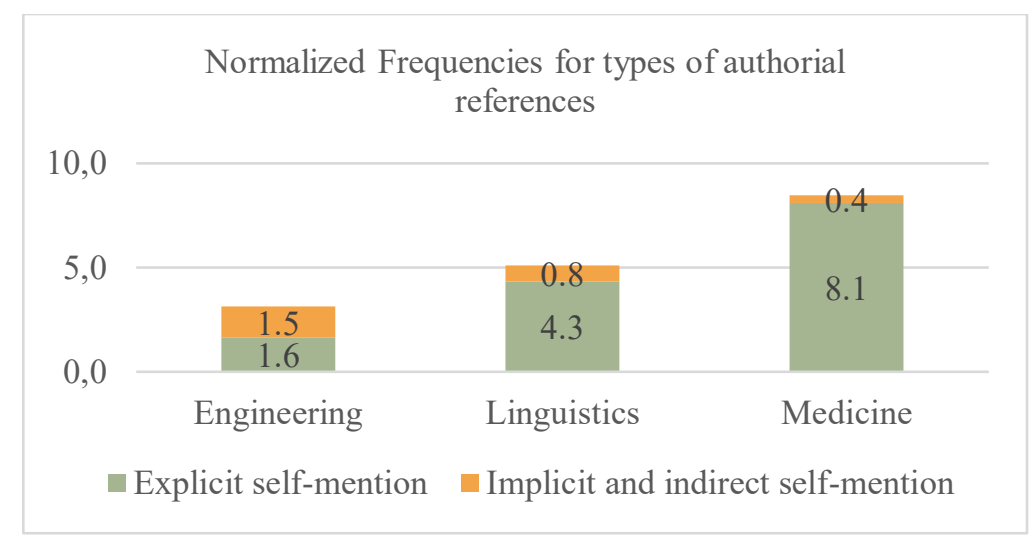

Figure 1. Normalized frequencies for types of authorial references across disciplines.

If we look at the way researchers employ authorial references across RAs sections, Table 3 below shows that when frequencies are normalized, introductions tend to concentrate a higher amount of authorial self-references per 1,000 words, compared to the post-method sections in all disciplines with the exception of RAs in the field of Engineering. This seems to suggest that researchers make themselves more visible in 
the introductions, where the rhetorical functions deployed tend to be less facethreatening, than in the post-methodology ones, except for the field of Engineering.

However, other studies have shown a different distribution of these elements along the text. For example, Martínez (2005) found that first-person pronouns, or explicit devices, tended to concentrate in the results and discussion sections of Biology papers. In contrast, Carciu (2009) found that the pronoun 'we'was more frequently deployed in the introduction and discussion section of medical RAs. On its part, Lorés-Sanz (2011b) in her contrastive study in the discipline of Business Management, showed that pronouns tended to concentrate in the methodology and discussion sections.

As for the type of authorial reference most frequently enacted across sections, findings indicate that in the introductory sections, implicit self-mentions are slightly more common in the discipline of Engineering, whereas in Linguistics and Medicine researchers employ more explicit devices in the introductions than indirect or implicit ones. This finding coincides with Ebrahimi and Chan (2014)'s research on the discourse functions of grammatical subjects in the results and discussion sections of RAs across four disciplines. They showed that first person pronouns were absent in Civil Engineering RAs, somehow supporting the view that Engineering is a discipline where researchers avoid portraying themselves as responsible for findings or interpretations (Davies, 1988).

Table 3. Raw counts and normalized frequencies of the different types of authorial references across disciplines and RA sections.

\begin{tabular}{|l|c|c|c|c|c|l|}
\hline & \multicolumn{2}{|c|}{ Engineering } & \multicolumn{2}{c|}{ Linguistics } & \multicolumn{2}{c|}{ Medicine } \\
\hline \multicolumn{1}{|c|}{ Types of authorial references } & Intro & Post-M & Intro & Post-M & \multicolumn{1}{c|}{ Intro } & Post-M \\
\hline Explicit self-mention & $(9) 1.1$ & $(50) 1.7$ & $(58) 5.2$ & $(184) 4.1$ & $(42) 15.3$ & $(148) 7.1$ \\
\hline Implicit and indirect self-mention & $(16) 1.9$ & $(41) 1.4$ & $(29) 2.6$ & $(14) 0.3$ & $(7) 2.5$ & $(2) 0.1$ \\
\hline Total & $(25) 3.0$ & $(91) 3.1$ & $(87) 7.9$ & $(198) 4.4$ & $(49) 17.8$ & $(150) 7.2$ \\
\hline
\end{tabular}

Results from the application of the statistical tool 'chi square' have shown that authorial references are distributed in a way that is statistically different across the three disciplines and the different sections analysed. In other words, disciplinary variation seems to be the driving force for differences in the frequency of occurrence with which researchers make themselves visible across disciplines. The differences in the way authorial devices are employed across the three disciplines is statistically significant both for the introduction and post-method sections with a $\mathrm{p}$ value of $<0.001$. More specifically, explicit devices are employed differently in the three disciplines under analysis and this difference is statistically relevant with a $\mathrm{p}$ value of $<0.001$ both for the introduction and post-method sections. Regarding the implicit/indirect self-mention devices, it cannot be concluded that there is a statistical significant difference in their frequency of use in the introductory parts ( $p$. value 0.578 ) but their use is significant in the post-method sections (p. value $<0.001)$. 


\subsection{Frequency and distribution of pragmatic/discourse functions across sections and disciplines}

In this section I will look into how the pragmatic functions identified are carried out across sections and disciplines. I have applied the chi square tool in order to assess whether there are statistically significant differences in the way the different pragmatic functions identified are enacted across the three disciplines and the different sections analysed.

As stated in previous research, it was expected that some of the functions were employed in a particular section as a result of its rhetorical purpose. Functions were considered as 'major' when they were attested at a minimum of 0.1 per 1,000 words in at least two of the disciplines under analysis. Table 4 below shows the presence/absence pattern of the different pragmatic functions per section and discipline.

Table 4. Presence or absence of discourse/pragmatic functions per section and discipline.

\begin{tabular}{|l|c|c|c|c|c|c|}
\hline $\begin{array}{l}\text { Pragmatic/Discourse } \\
\text { Functions }\end{array}$ & $\begin{array}{c}\text { Eng } \\
\text { Intro }\end{array}$ & $\begin{array}{c}\text { Eng Post- } \\
\text { meth }\end{array}$ & $\begin{array}{c}\text { Ling } \\
\text { Intro }\end{array}$ & $\begin{array}{c}\text { Ling Post- } \\
\text { meth }\end{array}$ & $\begin{array}{c}\text { Med } \\
\text { Intro }\end{array}$ & $\begin{array}{c}\text { Med Post- } \\
\text { meth }\end{array}$ \\
\hline 1. Stating a purpose & $\sqrt{ }$ & $\sqrt{ }$ & $\sqrt{ }$ & $\sqrt{ }$ & $\sqrt{ }$ & $\sqrt{ }$ \\
\hline 2. Explaining a procedure & $\sqrt{ }$ & $\sqrt{ }$ & $\sqrt{ }$ & $\sqrt{ }$ & $\sqrt{ }$ & $\sqrt{ }$ \\
\hline 3. Stating a result/ claim & 0 & $\sqrt{ }$ & $\sqrt{ }$ & $\sqrt{ }$ & 0 & $\sqrt{ }$ \\
\hline 4. Elaborating an argument & $\sqrt{ }$ & $\sqrt{ }$ & $\sqrt{ }$ & $\sqrt{ }$ & 0 & $\sqrt{ }$ \\
\hline 5 Limitation-hedging & 0 & $\sqrt{ }$ & $\sqrt{ }$ & $\sqrt{ }$ & $\sqrt{ }$ & $\sqrt{ }$ \\
\hline 6 Contribution/ application & $\sqrt{ }$ & $\sqrt{ }$ & $\sqrt{ }$ & $\sqrt{ }$ & 0 & $\sqrt{ }$ \\
\hline 7 Future work & 0 & $\sqrt{ }$ & $\sqrt{ }$ & $\sqrt{ }$ & 0 & $\sqrt{ }$ \\
\hline 8 Organizing discourse & $\sqrt{ }$ & 0 & $\sqrt{ }$ & $\sqrt{ }$ & 0 & 0 \\
\hline
\end{tabular}

The discipline with the most rhetorically complex pattern is that of Linguistics, as all the functions are deployed in both sections ${ }^{5}$. This discipline is followed by Engineering and then Medicine, which is the least complex from a rhetorical point of view, despite being the discipline which deploys the highest number of authorial devices per 1,000 words. Medicine introductions do not state results, or elaborate arguments and they do not signal contributions, future work or the organization of discourse functions. This seems to indicate that introductions are shorter and straight to the presentation of purpose, procedures and occasionally to the indication of a limitation or gap which the current piece of research will fill in.

In contrast, post-method sections in Medicine papers are more complex and include all the functions except for the organization of discourse. The Engineering papers incorporate all the functions in the post-method sections, whereas introductions tend to just include goals and procedures, the elaboration of an argument, contributions and applications and the signalling of the different sections of the paper. 
Thus, only the presentation of aims and the description of procedures are employed in all the disciplines and sections. Although function 1 is more typical of introductions, all the disciplines include some mention of aims in the post-method sections as well.

\subsubsection{Pragmatic functions in RAs across the three disciplines}

In what follows, I will provide the percentages of occurrence of the different pragmatic functions identified across the different sections of the three disciplines under analysis (see Figures 2 and 3 below). The two main sections have been kept separate in order to obtain a general picture of how different functions are deployed in each of the sections, bearing in mind their main rhetorical function(s).

The most frequently enacted function in the introductory sections of Engineering papers is that of stating a purpose (64\%), followed, at a large difference, by explaining procedures, elaborating and argument, indicating limitations and pointing to the organisation of discourse functions with a percentage of $8 \%$ for all of them. Post method sections in Engineering are mostly devoted to the elaboration of an argument $(41 \%)$, the stating of a result or claim $(21 \%)$, and the stating of a purpose $(11 \%)$ or the explaining of a procedure $(10 \%)$ with quite similar percentages.

In the field of Linguistics, the main pragmatic functions in introductions are mostly about stating goals (34\%), explaining procedures $(28 \%)$ but also about elaborating an argument (21\%), which indicates that writers make a conscious effort at justifying their findings in the promotional site of the introductions, perhaps as a way to highlight the relevance of their research. In this section, claims or results are also advanced $(10 \%)$ as are all the rest of functions with different percentages of appearance. All this indicates a meticulous concern with the need to include as many rhetorical functions as possible, a somehow distinctive feature of disciplines in the humanities. Post-method sections are mostly concerned with the explanation of procedures and the stating of results with $62 \%$, while also with the elaboration of the arguments $(52 \%)$.

Finally, in the field of Medicine, introductions are mainly about explaining procedures $(58 \%)$ and stating a purpose $(39 \%)$. The fact that explaining procedures has a higher distribution per 1,000 words than the stating of a purpose, that is, 6.9 versus 4.7 , seemingly indicates that, at least in this corpus, methodological concerns are of key importance for researchers in the medical field. Thus, it seems that it is key to the discipline to introduce or present in detail the procedure followed, perhaps, to make the piece of research different or unique in an attempt to make the contribution stand out amongst others. In post-method sections, researchers in the medical field mainly elaborate on their arguments $(46 \%)$, state claims $(24 \%)$ and also explain a procedure $(15 \%)$. 


\section{Percentages of occurrence of the pragmatic functions in Introductions}

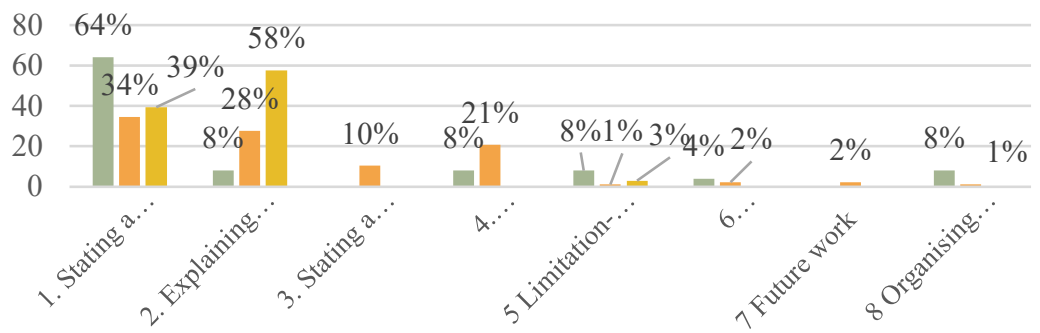

$\square$ Engineering introductions \% $\square$ Linguistics Intro\% $\square$ Medicine Intro\%

Figure 2. Percentages of occurrence of the pragmatic functions in introductions.

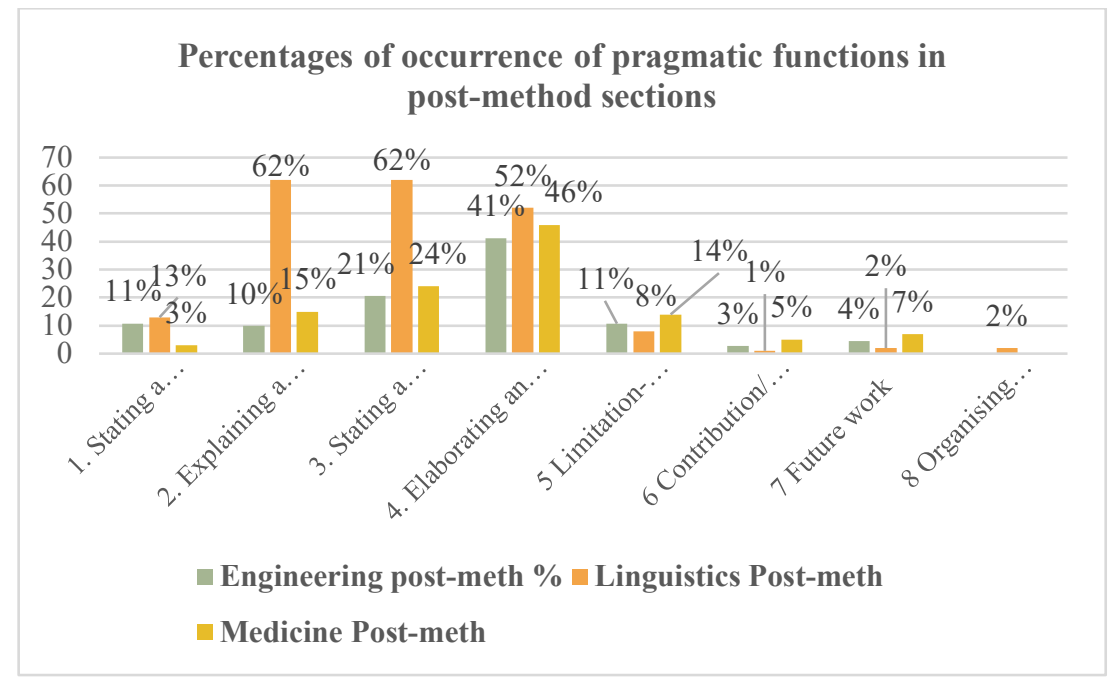

Figure 3. Percentages of occurrence of pragmatic functions in post-method sections.

In spite of the calculation of the overall percentages of occurrence of the different pragmatic functions across sections and/or disciplines, the chi square tool has also been applied in order to assess whether there are statistically significant differences in the way the different pragmatic functions identified are enacted across the three disciplines and the different sections analysed.

Table 5 below indicates that only functions 1 (state goals) and 8 (organise discourse) are used in a fairly similar way in all the three disciplines under analysis across both the sections under analysis; that is, researchers in these fields state goals and organise discourse both in the introduction and post-method sections with varying degrees of frequency, but with no significant difference from a statistical point of view. 
On the contrary, the way researchers make use of the rest of the pragmatic functions is discipline and/or section sensitive. In the introductory parts, the explanation of procedures, the statement of results and the elaboration of arguments are three functions which researchers deploy with different frequencies from a statistical point of view. In the post-method sections, the explanation of procedures, the elaboration of arguments, the expression of limitations, contribution or applications and the signalling of future avenues for work, are enacted with varying different, and statistically significant frequencies, in the three disciplines analysed, as corroborated by the $\mathrm{p}$ values in the table below:

Table 5. Chi-square values and pragmatic functions across paper sections.

\begin{tabular}{|l|c|c|}
\hline \multicolumn{1}{|c|}{ Pragmatic Functions } & \multicolumn{2}{c|}{ P-VALUES } \\
\hline & Intro & Post-method \\
\hline 1. State goals & 0.043 & 0.221 \\
\hline 2. Explain procedure & $<0.001^{*}$ & $<0.001^{*}$ \\
\hline 3. State results & $0.011^{*}$ & 0.069 \\
\hline 4. Elaborate argument & 0.001 & $0.005^{*}$ \\
\hline 5. Limitations & 0.306 & $0.013^{*}$ \\
\hline 6. Contribution or application & 0.756 & $0.022^{*}$ \\
\hline 7. Future work & 0.365 & $0.015^{*}$ \\
\hline 8. Organise discourse & 0.549 & 0.186 \\
\hline
\end{tabular}

\section{CONCLUDING REMARKS}

The main aim of this paper was to compare the way researchers make themselves visible through the use of what I have labelled in this paper explicit, implicit, and indirect authorial device in three disciplines which can be placed alongside the hardsoft disciplines cline (Becher, 1989). Drawing on previous taxonomies and after a thorough analysis of the introduction and post-methodology sections of 30 papers, I have devised my own taxonomy of the main pragmatic functions that these selfmentions perform across these sections in the three disciplines. The introduction was selected due to its potential as a promotional site. Since the papers selected did not conform to the IMRD structure, all the sections after the methodology were merged into what has been termed 'post-method sections'. Both sections were expected to perform a series of rhetorical functions which would require the researchers to make themselves visible with varying degrees of intensity as complex rhetorical sections. In order to determine whether there were any statistical difference in the frequency and distribution of these devices across sections and disciplines, I applied the chi square tool and normalized the three sub-corpora to make comparisons possible.

Findings from the comparison of the way researchers deploy authorial devices in the introduction and post-method sections of a corpus of 30 papers from the disciplines of engineering, linguistics and medicine, have indicated that researchers in 
each of the fields of study have a different way of making themselves visible in their papers.

Such differences and preferences for the use of various authorial devices with varying frequencies may be brought about by either the researchers' own writing style but also by the rhetorical conventions of the discipline to which they belong. Findings have indicated that the so-called indirect or implicit authorial devices are employed with less frequency than the explicit devices, i.e., first person pronouns and their corresponding possessive pronouns and determiners, a finding corroborated by previous research. Thus, it is the first person pronouns and its corresponding determiners and possessive pronouns the self-mention devices which are most commonly deployed by researchers. However, engineering is the discipline which tends to employ a lesser amount of explicit authorial devices, and which relies on other indirect or implicit ways of author presentation. A closer look has been paid to the way these devices are employed across different sections. Whereas some of the disciplines participate of a higher number of pragmatic functions in both sections, for example, linguistics, medicine is the least complex from a rhetorical point of view. This somehow suggest that the conventions in this discipline compel writers to focus on the presentation of goals and detailed descriptions of procedures in introductions, whereas the rest of functions are somehow given less priority. This contrasts with the fact that medicine is the discipline which employs more self-mentions per 1,000 words. This makes the discipline one where author visibility becomes a must, especially if we consider that RA papers tend to be shorter than in the other disciplines. In contrast, engineering stands out as the discipline which employs less explicit devices per 1,000 words, although introductions and post-method sections are quite rich from a rhetorical point of view and tend to resort to a variety of functions.

The application of the statistical chi square tool has offered interesting findings, and has helped corroborated that disciplinary issues lie at the core of differences in the way these devices are employed across the different sections of the disciplines under analysis. Regarding the pragmatic functions enacted, except for the presentation of goals and the organisation of discourse, the rest of the functions are deployed in ways which are statistically significant across sections and disciplines.

Although the findings obtained can be deemed to be somehow preliminary, this paper opens up venues for further research. The results obtained here should be further investigated in a wider corpus and from a contrastive point of view. In other words, in a second phase, the choices made by native speakers of English regarding authorial presence should be compared to those made by Spanish researchers when writing papers in English in the journals analysed. On the other hand, although there is evidence that disciplinary issues are responsible for differences in the way researchers make use of authorial references, the corpus should also be expanded and 
the results obtained here should be further replicated with special attention to the different sub-disciplines within each of the main domains. In other words, more research needs to be conducted in order to map out variations not only across different disciplines but also sub-disciplines within broader areas of knowledge labelled as soft or hard disciplines.

In any event, the results obtained here could be certainly used to devise teaching materials in the disciplines analysed and to inform particular guidelines and resources for each of the disciplines. For example, specific seminars can be designed in which novel researchers are asked to collect samples of RAs to compare their own authorial choices with those of professional scholars in the field. This will foster an awareness of the specific authorial choices available for them to fulfil different pragmatic functions and will help them reflect on their own choice of strategies for writer visibility when writing in English. Likewise, results could be useful for writing instructors and teachers as they are responsible for raising students' awareness regarding the advantages or disadvantages of maintaining the generic conventions of the genre they are writing and of the disciplinary context to which they belong. Last, but not least, a more detailed qualitative analysis on the pragmatic functions enacted by the main explicit devices identified will also be of interest, in order to account for whether these functions fall within the more or less face-threatening side of the continuum.

\section{REFERENCES}

Abdollahzadeh, E. (2010). Poring over the findings: Interpersonal authorial engagement in applied linguistics papers. Journal of Pragmatics, 43, 288-297.

Albalat-Mascarell, A. \& Carrió-Pastor, M. L. (2019). Self-representation in political campaign talk: A functional metadiscourse approach to self-mentions in televised presidential debates. Journal of Pragmatics, 147, 86-99.

Becher, T. (1989). Academic tribes and territories. Buckingham: Society for Research into Higher Education \& Open University Press.

Berkenkotter, C. \& Huckin, T. (1995). Genre knowledge in disciplinary. Hillsdale, MJ: Lawrence Erlbaum.

Bloor, M. \& Bloor, T. (1991). Cultural expectations and socio-pragmatic failure in academic writing. In P. Adams, B. Heaton \& P. Howarth (Eds.), Socio-cultural issues in English for academic purposes (pp. 1-12). London: MacMillan Publishers Ltd.

Bondi, M. (2010). Metadiscursive practices in Introductions: Phraseology and Semantic Sequences across Genres. Nordic Journal of English Studies, 9(2), 99123. 
Breivega, K. R., Dahl, T. \& Flottum, K. (2002). Traces of self and others in research articles. A comparative pilot study of English, French and Norwegian research articles in medicine, economics and linguistics. International Journal of Applied Linguistics, 12(2), 218-239.

Burgess, S., Gea-Valor, MaLl, Moreno, A. I. \& Rey-Rocha, J. (2014). Affordances and constraints on research publication: A comparative study of the language choices of Spanish historians and psychologists. Journal of English for Academic Purposes, 14, 72-83.

Cadman, K. (1997). Thesis writing for international students: A question of identity? English for Specific Purposes, 16(1), 3-14.

Carciu, O. (2009). An intercultural study of first-person plural references in biomedical writing. Ibérica, 18, 71-92.

Carrió-Pastor, M. L. (2016). Mitigation of claims in medical research papers: A comparative study of English and Spanish writers. Communication and Medicine, 13(3), 249-261 [on line]. Retrieved from: http://hdl.handle.net/10251/80668.

Carrió-Pastor, M. L. (2019). Authorial engagement in business emails. Engagement in professional genres. In C. Sancho-Guinda (Ed.), Engagement in Professional Genres (pp 48-65). Pragmatics and Beyond New Series.

Carrió, M. L. \& Muñiz-Calderón, R. (2015). A contrastive analysis of metadiscourse features in business e-mails written by non-native speakers of English. Procedia-Social and Behavioural Sciences, 173, 214-221.

Chang, Y. \& Swales, J. (1999). Informal elements in English academic writing: Threats or opportunities for advanced non-native speakers. In C.N. Candlin \& K. Hyland (Eds.), Writing: Texts processes and practices (pp. 145-147). London: Longman.

Cherry, R. D. (1988). Ethos versus persona: Self-representation in written discourse. Written communication, 5, 251-276.

Connor, U. (1996). Contrastive rhetoric: Cross-cultural aspects of second language writing. Cambridge: Cambridge University Press.

Davies, F. (1998). Reading between the lines: thematic choices as a device for presenting writers viewpoint in academic discourse. Especialist, 9, 173-200.

Del Saz-Rubio, M. M. (2019). A contrastive genre-based approach to the rhetorical structure and use of interactional metadiscourse in the results and discussion section of Food Science \& Technology Papers. Miscelánea: A Journal of English and American Studies, 59, 13-45. 
Ebrahimi, S. F. \& Chan, S. H. (2014). Discourse functions of grammatical subject in result and discussion sections of research article across four disciplines. Journal of Written Research, 6(2), 125-140.

Flottum, K., Kinn, T. \& Dahl, T. (2006). We now report on Versus Let us now see how: Author roles and interaction with readers in research articles. In $\mathrm{K}$. Hyland \& M. Bondi (Eds.), Academic discourse across disciplines (pp. 203-224). Bern: Peter Lang.

Flowerdew, J. \& Li, Y. (2009). English or Chinese? The trade-off between local and international publication among Chinese academics in the humanities and social sciences. Journal of Second Language Writing, 18, 1-6.

Fortanet, I. (2004). Enhancing the speaker-audience relationship in academic lectures. In P. Garcés, R. Gómez, L. Fernández \& M. Padilla (Eds.), Current trends in intercultural cognitive and social pragmatics (pp. 83-96). Sevilla: Universidad de Sevilla.

Geertz, C. (1983). Local knowledge: Further essays in interpretive Anthropology. New York: Basic Books.

Gosden, H. (1993). Discourse functions of subject in scientific research articles. Applied Linguistics, 14(1), 56-75.

Hardwood, N. (2005a). Nowhere has anyone attempted ... In this article I aim to do just that. A corpus-based study of self-promotional $I$ and we in academic writing across four disciplines. Journal of Pragmatics, 37, 1207-1231.

Hardwood, N. (2005b). We do not seem to have a theory...the theory I present here attempts to fill this gap: Inclusive and exclusive pronouns in academic writing. Applied Linguistics, 26, 343-375.

Hunston, S. (1993). Evaluation and ideology in scientific writing. In M. Ghadessy (Ed.), Register analysis: Theory and practice (pp. 57-73). London: Pinter.

Hunston, S. (1994). Evaluation and organization in a sample of written academic discourse. In M. Coulthard (Ed.), Advances in written text analysis (pp. 191-218). London: Routledge.

Hyland, K. (1994). Hedging in academic writing and EAP textbooks. English for Specific Purposes, 13, 239-256.

Hyland, K. (1996). Writing without conviction? Hedging in science research articles. Applied Linguistics, 17(4), 433-454.

Hyland, K. (1998). Hedging in scientific research articles. Amsterdam: John Benjamins. 
Hyland, K. (1999). Disciplinary discourses: Writer stance in research articles. In C. N. Candlin, \& K. Hyland (Eds.), Writing: Texts, processes and practices (pp. 99-121). London: Longman.

Hyland, K. (2000). Disciplinary discourses: Social interaction in academic writing. London: Pearson.

Hyland, K. (2001a). Humble servants of the discipline? Self-mention in research articles. English for Specific Purposes, 20, 207-226.

Hyland, K. (2001b). Bringing in the reader: Addressee features in academic articles. Written Communication, 18(4), 549-574.

Hyland, K. (2002a). Activity and evaluation: reporting practices in academic writing. In J. Flowerdew (Ed.), Academic Discourse (pp. 115-130). Longman. Harlow.

Hyland, K. (2002b). Authority and invisibility: Authorial identity in academic writing. Journal of Pragmatics, 34, 1091-1112.

Hyland, K. (2005). Metadiscourse. London: Continuum.

Hyland, K. \& Tse, P. (2005) Evaluative 'that' constructions. Signalling stance in research abstracts. Functions of Language, 12(1), 39-63.

Ivanič, R. (1994). I is for interpersonal: Discoursal construction of writer identities and the teaching of writing. Linguistics and Education, 6(1), 3-15.

Ivanič, R. (1995). Writer identity. Prospect, 10(1), 8-31.

Ivanič, R. 1998. Writing and identity: The discoursal construction of identity in academic writing. Amsterdam: John Benjamins.

Ivanič, R. \& Camps, D. (2001). I am how I sound: Voice as self-representation in L2 writing. Journal of Second Language Writing, 10(1-2), 3-33.

Kuo, C.H. (1999). The use of personal pronouns: Role relationships in scientific journal articles. English for Specific Purposes, 18(2), 121-138.

Lafuente-Millán, E. (2010). Extending this claim, we propose... The writer's presence in research articles from different disciplines. Ibérica, 20, 35-56.

Landis, J. R. \& Koch, G. G. (1977). The measurement of observer agreement for categorical data. Biometrics, 33, 159-174.

Law, J. \& Williams, R. J. (1982). Putting facts together: A study of scientific persuasion. Social Studies of Science, 12, 535-558.

Lester, J. D. (1993). Writing research papers (7th ed.). New York: Harper Collins. 
Li, Y. (2014). Seeking entry to the North American market: Chinese management academics publishing internationally. Journal of English for Academic Purposes, 13, 41-52.

Lin, L. \& Evans, S. (2012). Structural patterns in empirical research articles: A crossdisciplinary study. English for Specific Purposes, 31, 150-160.

López, I., Moreno, A. I. \& Rey-Rocha, J. (2017). Dificultades de los investigadores españoles para publicar en revistas internacionales: Métricas, editores y multilingüismo. Teknokultura, 14(1), 13-33.

Lorés-Sanz, R. (2004). On RA abstracts: From rhetorical structure to thematic organization. English for Specific Purposes, 23(3), 280-302.

Lorés-Sanz, R. (2008). Authorial visibility in research article and research article abstracts: The intergeneric perspective. In S. Burgess \& P. Martín Martín (Eds.), English as an additional language in research publication and communication (pp. 105-122). Bern: Peter Lang.

Lorés-Sanz, R. (2011a). The construction of the author's voice in academic writing: The Interplay of Cultural and Disciplinary Factors. Text \& Talk, 31, 173-193.

Lorés-Sanz, Rosa (2011b). The study of authorial voice: Using a Spanish-English corpus to explore linguistic transference. Corpora, 6(1), 1-24.

Luzón, M. J. (2006). The rhetorical function of the lexical signalling of the author's presence in the experimental biomedical paper. Unpublished doctoral dissertation. University Jaume I, Castellón, Spain.

Martínez, I. A. (2005). Native and non-native writer's use of first person pronouns in the different sections of biology research articles in English. Journal of Second Language Writing, 14,174-190.

Martín-Martín, P., Rey-Rocha, J., Burgess, S. \& Moreno, A. I. (2014). Publishing research in English-language journals: Attitudes, strategies and difficulties of multilingual scholars of medicine. Journal of English for Academic Purposes, 16, 57 67.

McDonald, S. P. (1992). A method for analysing sentence-level differences in disciplinary knowledge making. Written Communication, 9(4), 533-569.

McGrath, L. (2014). Parallel language use in academic and outreach publication: A case study of policy and practice. Journal of English for Academic Purposes, 13, 5 16. 
Moreno, A. I. \& Swales, J. M. (2018). Strengthening move analysis methodology towards bridging the function-form gap. English for Specific Purposes, 50, 40-63 [on line]. Retrieved form: https://doi.org/10.1016/j.esp.2017.11.006

Moreno, A. I., Rey-Rocha, J., Burgess, S., López-Navarro, I. \& Sachdev, I. (2012). Spanish researchers' perceived difficulty writing research articles for Englishmedium journals: The impact of proficiency in English versus publication experience. Ibérica, 24, 157-183.

Mur-Dueñas, P. (2007). I/We focus on...: A cross-cultural analysis of self-mentions in business management research articles. Journal of English for Academic Purposes, 6,143-162.

Nwogu, K. (1997). The medical research paper: Structure and functions. English for Specific Purposes, 16(2), 119-138.

Rowntree, K. (1991). Writing for success. Auckland: Longman Paul.

Salager-Meyer, F. (2014). Writing and publishing in peripheral scholarly journals: How to enhance the global influence of multilingual scholars? Journal of English for Academic Purposes, 13, 78-82.

Sancho-Guinda, C. (2015). How detached is technical writing? Teaching interpersonality with NTSB aircraft-accident dockets online. Procedia-Social and Behavioral Sciences, 173, 138-142.

Shaw, P. \& Vassileva, I. (2009). Co-evolving academic rhetoric across culture; Britain, Bulgaria, Denmark, Germany in the 20 ${ }^{\text {th }}$ century. Journal of Pragmatics, 41(2), 290-305.

Shaw, P. (2003). Evaluation and promotion across languages. Journal of English for Academic Purposes, 2(4), 343-357.

Tang, R. \& John, S. (1999). The 'I' in identity: Exploring writer identity in student academic Writing through the first person pronoun. English for Specific Purposes, 18 (Suppl.), S23-S39.

Thompson, G. \& Thetela, P. (1995). The sound of one hand clapping: The management of interaction in written discourse. Text and Talk, 15(1), 103-127.

Thompson, G. \& Ye, Y. (1991). Evaluation in the reporting verbs used in academic papers. Applied Linguistics, 4, 365-382.

Vassileva, I. (1998). Who am I/who are we in academic writing? A contrastive analysis of authorial presence in English, German, French, Russian and Bulgarian. International Journal of Applied Linguistics, 8(2), 163-190. 
Vassileva, I. (2000). Who is the author? A contrastive analysis of authorial presence in English, German, French, Russian and Bulgarian academic discourse. Sankt Augustin: Asgard Verlag.

Vassileva, I. (2001). Commitment and detachment in English and Bulgarian academic writing. English for Specific Purposes, 20, 83-112.

\section{*ACKNOWLEDGEMENTS}

I would like to express my sincere gratitude to the anonymous reviewers of this paper for their enlightening and pertinent comments, which have helped me greatly improve the final version of it. This article is also a contribution to the research project "Identification and analysis of rhetoric elements in Spanish and in English: a study of metadiscoursive strategies" (FFI2016-77941-P).

\section{APPENDIX}

Corpora journal list

\begin{tabular}{|l|l|l|}
\hline \multicolumn{1}{|c|}{ Engineering corpus } & \multicolumn{1}{|c|}{ Medicine corpus } & \multicolumn{1}{c|}{ Linguistics corpus } \\
\hline Plant Soil & American Journal of Infection & Language, Cognition and \\
Journal of Construction & Control & Neuroscience \\
Engineering \& Management & JACC Cardiovascular & Journal of Linguistics \\
IEE Transactions on Industrial & Interventions & English for Specific Purposes \\
Informatics & Journal of Psychiatric Research & Journal of English for \\
European Journal of Agronomy & Cancer & Academic Purposes \\
Reliability Engineering \& System & British Medical College & Applied Linguistics \\
Safety & & \\
\hline
\end{tabular}

\section{NOTES}

1 The methodology section has not been considered for analysis due to time and space limitations but also because it is not such a highly charged rhetorical section in comparison with the introduction and the post-method although it is true that some studies (Lorés-Sanz, 2011b) have shown that authorial devices are quite pervasively employed in this section.

2 The functions of originator and opinion holder are also indicated in Vassileva's taxonomy in combination with verbs of emotion or thinking (think, believe, hope, fear, etc.).

${ }^{3}$ As this is a preliminary study of the use of authorial devices in papers which do not follow the default IMRD structure, no further distinction among disciplines has been carried out at this stage. 
${ }^{4}$ Considering that this paper has as its aim to analyze visible or more personal markers of authorial presence, the use of passive structures, which would be located on the other side of the cline for the (un)visibility of researchers, will not be tackled as they are devices which convey a higher detachment of the RA's writer.

${ }^{5}$ For the purpose of this paper, rhetorical complexity has been estimated considering the realization of pragmatic functions via the use of authorial devices. However, one might argue that some of these functions could also be realized without the presence of an authorial device. 